\title{
A Practice-Oriented Definition of Post-Process Second Language Writing Theory
}

Amir Kalan

This article is a synthesis of the scholarly literature on the post-process approach to teaching second language (L2) writing, particularly college and university composition in English as an additional language. This synthesis aims to offer a definition of post-process $L 2$ writing that can readily lend itself to practice and be more accessible to practitioners. All the publications that had either substantially or marginally discussed post-process theory since 1990 were systematically reviewed in order to answer the following question: What is a definition of post-process L2 writing theory that can readily lend itself to pedagogy and actual practice for helping college and university writers of English as an additional language?

Cet article est une synthèse de la littérature savante sur la méthode post-processus de l'enseignement de la rédaction en langue seconde (L2), notamment de l'écriture dans les cours d'anglais langue additionnelle dans les collèges et les universités. L'objectif de cette synthèse est de proposer une définition de la rédaction post-processus en L2 qui puisse se prêter facilement à la pratique et être plus accessible aux praticiens. On a examiné systématiquement toutes les publications ayant porté, ou même évoqué, la théorie du post-processus depuis 1990 et ce, de sorte à répondre à la question suivante: Quelle définition de la rédaction post-processus en L2 peut facilement se prêter aux fins pédagogiques et pratiques dans les cours d'anglais langue additionnelle dans les collèges et les universités?

Since the beginning of the 1970s, process writing theory has dominated the field of composition studies and inspired classroom practice. Process writing pedagogy (White \& Arndt, 1991) is still revered as a source of creative strategies for teaching academic writing. Replacing the traditional product-based pedagogy that mainly evaluated students' final written products, process pedagogy helped teachers regard writing as a process rather than a product (White, 1988). Trying to help students emulate "good writers" (White, 1988, p. 9), process writing theory invited students to brainstorm, prewrite, multidraft, edit, receive feedback from peers and teachers, revise, and publish. The process approach to teaching writing was also adopted in L2 writing classes (Susser, 1994). However, some advocates of post-process writing theory believe that "there is little hard evidence that [process approaches] lead to significantly better writing in L2 contexts" (Hyland, 2003, p. 17). Post-process 
writing scholars have long talked about the need to move beyond process writing and to broaden the current paradigms in L2 language writing pedagogy in a post-process era.

The present article aims to clearly delineate the main concerns of postprocess writing theorists in the form of a definition. Several characteristics of the synthesis should be noted. First, for the purposes of this article, the literature on post-process writing theory was analyzed through the prism of its impact on L2 writing, especially academic writing in English as a second language. Second, there was a deliberate attempt to shape a definition that can readily inform practice. Third, the focus of this synthesis was on adult writing in general and college and university writing in particular. This focus happened partly because of an attempt to narrow down the scope of the project and partly because most of the literature about post-process composition studies related such experiences.

In this article, after a discussion of the significance of the study and the methods employed for this synthesis, the results of the analysis of the views of post-process theorists will be presented in the form of a detailed definition with reference to seven focal arguments in post-process theory.

\section{Importance of the Study}

L2 writing research seems at times oddly insular, not even referencing work in second language acquisition much, not to mention other contemporary thinking that might help both to clarify and complexify our project. Are we in L2 writing missing out, being bypassed by the most interesting intellectual trends of our times[?] (Leki, 2003, p. 103)

A systematic focus on the characteristics of post-process theory and a serious exploration of its potentials for improving the quality of teaching L2 writing are necessary for three reasons: the increasing popularity of post-positivist theories and socially embedded pedagogical practices, the uncomfortable relationship between post-process theory and classroom pedagogy, and the gap regarding metadisciplinary research in L2 writing research. First of all, the emergence of post-positivist philosophical frameworks such as "use theories" of linguistic meaning (Lycan, 2000), post-structuralism, and neopragmatism (linguistic pragmatism) in humanities, social sciences, and educational research demands speculations about recasting theories, pedagogies, and practices in all venues related to literacy, including L2 writing. After the failure of early analytic philosophy to reduce language to logical statements (Kaplan, 1972; Russell, 2005) and, accordingly, to replace philosophy with "the logic of science - that is to say, with the logical analysis of the concepts and sentences of the sciences, for the logic of science is nothing other than the logical syntax of the language of science" (Carnap, 1937, p. xiii), Wittgenstein's use theory 
of meaning (1958) allowed scholars to regard language use as "one constituent" of "a complex series of actions and practices" that humans, as social beings, partake in (Odell, 2006, p. 56). Poststructuralist philosophers added another layer to the social cocoon that, as revealed by use theorists, surrounds language. They gave frequent descriptions of how ideological language was (Derrida, 2001) and how profoundly power relations impacted text creation (Foucault, 2002).

This dramatic shift in the way language was viewed in Western philosophy, sooner or later, would propel academics and practitioners into approaching literacy teaching and learning as a sociocultural phenomenon rather than merely a set of techniques cognitively learned. Since the 1980s there has been a sense of urgency in different fields of education studies to broaden the definition of "literacy" in order to include societal and discursive relations that impact the teaching and learning of literacy (Barton \& Hamilton, 2000; Cazden et al., 1996; Gee, 2001; Heath, 1983; Heath \& Street, 2008; Simon, 2011; Street, 1993).

This "social turn" has also profoundly impacted second language education (Cummins, 2009). In the same fashion, there has been a conversation among L2 writing researchers about a shift from "cognitive skills" to "sociocultural practices and macro-societal structures" (Cumming, 2013b) and the multidimensional nature of L2 writing (Cumming, 2013a). Nevertheless, in comparison with other fields of literacy, "there have been far fewer attempts to understand specifically English L2 writing in critical, post-modernist, postcolonial terms" (Leki, 2003, p. 104). In the field of L2 writing, post-process L2 theory is one of the schools most receptive to sociocultural philosophical developments described above. Thus, a systematic review of the literature penned by the theorists and advocates of the post-process theory is indeed worthwhile.

Second, post-process theorists' stance against classroom pedagogy and their invitation to move beyond pedagogy (Sanchez, 2011) have generated doubts about the possibility of successful practice informed by or consistent with the theoretical speculations of post-process theory advocates (Fulkerson, 2005). However, although the paradigms of post-process theory might at times clash with the supply-and-demand realities that have created most of the institutions that teach writing in post-secondary settings, "postprocess theory can and should be made workable in our own classrooms, even if only in limited contexts" (Heard, 2008, p. 283). A practice-oriented synthesis of post-process theory literature can indeed help manifest the potentials of this scholarly conversation for actual practice. Accordingly, this article tries to offer a definition of post-process theory that can comfortably lend itself to pedagogy and practice rather than emphasize the theoretical edge of this movement.

Third, this study is a response to L2 writing researchers' call for more metadisciplinary research. In "Changing Currents in Second Language Writ- 
ing Research: A Colloquium" (Matsuda, Canagarajah, Harklau, Hyland, \& Warschauer, 2003), Matsuda invited researchers to conduct metadisciplinary inquiry into the recent developments in second language writing and to consider "a wide range of issues, including the definition and historical development of the field" (p. 171). Canagarajah, in the same paper, suggested creating generalizable models based on case study reports on individual writers, especially with an eye on practice: "[S]tudies on multiliteracies [in L2 writing] have to soon move from the current exploratory stage towards more analytical model building. We need to learn from the several case studies to form generalizations regarding effective practices and productive strategies" (p. 159). The present article is a response to these calls.

\section{Methods}

The data synthesized in this article were collected by a systematic review of English publications on post-process writing theory in composition studies and L2 writing theory with an eye on college composition and universitylevel writing. The data were collected through two different channels. First, the most important collective and individual academic attempts to create a writing movement beyond the process theory were identified. Afterwards, links, references, and examples of practice in these writings were followed and carefully examined. The publications that make the backbone of postprocess theory start from the writings of John Trimbur, who first used the term "post-process writing" (1994, p. 108), to Post-process Theory: Beyond the Writing-Process Paradigm (Kent, 1999), a collection of articles by a number of composition scholars, to the Journal of Second Language's special edition about L2 writing and post-process theory edited by Dwight Atkinson (2003a), and finally to Beyond Post-process (Dobrin, Rice, \& Vastola, 2011). All the articles in these collections were consulted to create a pool of data based on the references and links they provided.

Second, major online database systems of educational research - such as ERIC and ProQuest - were searched for the following key words: post-process theory, post-composition, critical composition pedagogies, hermeneutic guessing, and paralogic rhetoric. Post-process (recently also frequently spelled as postprocess) regards writing as a social and collaborative act rather than a certain technique that can be codified and taught to individuals. Post-composition, rather than the end of composition, indicates the transformation of composition studies as an academic discipline mainly because of the impact of new technologies and the popularity of postmodern views of writing that welcome new genres, forms of writing, and rhetorical patterns. Expressive pedagogy, rhetorical pedagogy, cultural studies writing pedagogy, social justice writing pedagogy, and basic writing pedagogy are examples of critical composition pedagogies, which have strong connections with post-process writing theory. Hermeneutic guessing is an expression first used by Kent (2011) to describe 
the interpretive agility required for the acts of text consumption and production in communication. "Paralogic rhetoric" (Kent, 1993) is the philosophical framework that some post-process theorists have employed to mobilize their arguments. All the expressions defined above were also searched, in a second round, accompanied by the terms L2 writing and second language writing in order to find publications that had specifically focused on post-process L2 language writing.

During the data collection and after it, when the size of the pool of data was deemed sufficient, all passages and statements that could contribute to a clear definition of post-process L2 writing theory were coded. The coded statements were filtered twice to keep only descriptions of post-process theory that, in accordance with the guiding question of this synthesis, would shed more light on how post-process theory specifically informed L2 writing pedagogy and practice. First, the content was narrowed down to explanations of post-process theory that could contribute to L2 writing. Second, priority of analysis was given to more practice-oriented statements. For instance, the post-process emphasis on broadening genre possibilities in composition classes in general (a major theme among the findings of this review) shares much with the scholarly conversation about intercultural rhetoric in L2 writing and thus could be conveniently borrowed by L2 writing teachers. Moreover, the post-process advice regarding exposing students to a variety of genres next to academic essay writing can be more comfortably employed by classroom teachers than similar themes in literature focusing more on philosophical descriptions of the capitalist roots of the Anglo-American essay as a dominant writing genre in the West. An emphasis on broadening genre possibilities thus gained more gravity during the process of data collection and analysis.

After narrowing down the coded descriptions of post-process, the remaining passages that were deemed, consistent with the criteria described above, to have practical implications in L2 writing classes were organized as seven focal arguments. These seven arguments, which will be presented in the next section, were deliberately extracted from the pool so that they could organically complement each other and create a harmonious image of a possible practice-oriented post-process L2 writing theory.

\section{Findings}

The findings of this synthesis will be presented in two steps. First will be a brief description of the characteristics of the definitions already available in post-process literature. Second, a definition of post-process theory in the form of seven arguments that could inspire L2 writing teachers will be presented.

Definitions of post-process writing theory are not rare in post-process literature. Most post-process theorists have defined the movement in a variety of depths and through different lenses (Atkinson, 2003a, p. 10; Blyler, 1999, 
p. 66; Casanave, 2003, p. 98; Clifford \& Ervin, 1999, p. 179; Couture, 2011, p. 24; Dobrin, 1999, p. 132; Dobrin et al., 2011, p. 1; Foster, 1999, p. 150; Fraiberg, 2002, p. 172; Kent, 1999, p. 5; Kent, 2011, p. xix; Petraglia, 1999, p. 53; Trimbur, 1994, p. 109). The majority of the definitions of post-process theory emphasize that post-process does not attempt to reject process theory but aims to extend its horizons through critical re-readings of it (Atkinson, 2003a; Couture, 1999, p. 31; Foster, 1999, p. 149). These definitions usually follow one (or occasionally both) of two trends. Some of these definitions represent post-process as containing what process theory lacks, which is, most importantly, due sensitivity to the sociocultural nature of writing in general and "sociocognitive situatedness, dynamism, [and] diversity" (Atkinson, 2003a, p. 10) of L2 writing in particular. The second trend in available definitions in post-process literature is defining post-process in philosophical terms. Some of these definitions are rooted in philosophy of language and semiotics (Kent, 2011, p. xix), and some, by "looking at the page as a unit of discourse" (Trimbur \& Press, 2011, p. 94), have a more poststructuralist nature.

Occupied with giving historical, ontological, and epistemological explanations for the necessity of a post-process theory, these definitions have not been constructed to be comfortably employed by teachers for everyday practice. Nevertheless, post-process literature is by no means void of descriptions that, if aggregated, can create a definition of post-process L2 writing theory with a viable practical edge.

A definition of post-process L2 theory can be presented in two interrelated descriptive threads. First, writing is not a single process that can be codified and taught (Blyler, 1999, p. 66; Olson, 1999, p. 7; Pullman, 1999, p. 27; Russell, 1999, p. 80). Assuming that writing can be reduced to one single process, in practice, has commonly resulted in the dominance of one particular genre that happens to fit that single process, namely Anglo-American academic writing. In order to deal with the problems caused by this reductionism, "essayist literacy" and the "rhetoric of assertion" as dominant composition discourses should be challenged (Burnham, 2001; Couture, 2011, p. 23; Root, 2003; Schilb, 1999) in order to broaden genre possibilities (Journet, 1999; Romano, 2000; Russell, 1999, p. 87). An extremely important corollary of challenging dominant genres would be providing students (particularly minority and marginalized students) with new forms of expression that can more readily connect to their identities. Thus, we need to move beyond assertive and essayist discourses in order to liberate students' agencies (Clifford \& Ervin, 1999, p. 118; Dobrin, 1999, p. 140; Ewald, 1999, p. 117).

Second, there is no simple pedagogy to be employed in the classroom in order to teach writing as an individual activity to students (Dobrin, 1999, p. 132; Ewald, 1999, p. 122; Pullman, 1999, p. 27; Russell, 1999, p. 81). Therefore, teachers need to move beyond the classroom as the only rhetorical situation and should question their role as the possessor of the techne of writing (Couture, 1999, p. 30; Ewald, 1999, p. 127; Petraglia, 1999, p. 49). Contrary to 
the popular view of writing as a technique-and, sometimes more culturally inclined, as an art-written texts should be seen as products of a complicated web of cultural practices, social interactions, power differentials, and discursive conventions (Atkinson, 2003a; Casanave, 2003; Howard, 2001). Thus, from a post-process perspective, learning L2 writing is basically learning knowledge design, rhetorical sensitivity, and hermeneutic guessing through a large number of literate activities (Casanave, 2003, p. 94; Clifford \& Ervin, 1999 , p. 179). In the following passage these arguments will be unpacked and presented as seven main focal arguments of post-process writing theory.

\section{A practice-oriented definition of post-process $L 2$ writing theory}

As mentioned in the introduction to this article, post-process theorists consciously resist any attempt to reduce their speculations to a set of pedagogical principles. They hold that

no principled pedagogy exists in the sense that we can stand outside our practices to discover a set of uncontested principles that will allow us to reject definitively one learning theory and to declare another the undisputed path to enlightenment. (Kent, 2002, p. 429)

This resistance is understandable. If we believe that teaching writing can be formulated in a clearly defined code, we have fallen back into the trap that restricted process theory, the belief in a certain codifiable exemplary process of writing that could be taught by a writing expert (the teacher) in any classroom.

This uncertainty about post-process pedagogy can unsettle practitioners who feel they need straightforward guidelines to offer to students attending their classes because of immediate needs such as passing standardized tests or completing their academic papers by a certain deadline. In fact, what practitioners might typically expect from a literacy theory is a clarification of the relations in the classroom-teacher-tests triangle, but this is precisely what post-process theory criticizes. Post-process theory cannot be reduced to a number of "principles" that "teachers" can use in the "classroom." Nevertheless, one can identify some centres of focus in post-process literature that can open spaces in post-process writing communities, where teachers collaborate with students to produce and distribute written texts for the betterment of their own lives and the lives of the people around them. In what follows, seven areas of focus in post-process theory will be discussed and their connections to actual practice will be highlighted.

\section{Writing cannot be reduced to a single codified process to be taught.}

Post-process theorists' harshest criticism of process writing is of the assumption that there is a single process employed by all successful writers. Researchers, from the perspective of process theory, are to discover this single cognitive process and codify it for classroom practice. Next, teachers, having 
been informed about the process, plan lessons that can walk their students through the "real" process of writing. Post-process theorists, however, believe there is no such thing as an ultimate process of writing:

[Process theory depends] on two incorrect assumptions about the writing act: first, that composing is a systematic, codifiable entity we can isolate and examine; second, that understanding and mastering this codifiable entity are necessary prerequisites to learning how to write. (Blyler, 1999, p. 66)

Olson (1999), in the same manner, is skeptical about the process orientation inasmuch as it "imagines that the writing process can be described in some way ... [and] process theorists assume that we can somehow make statements about the process that would apply to all or most writing situations" (p. 7). In contrast, since "[w]riting, whether the acts or the products of the acts, cannot be usefully theorized" (Pullman, 1999, p. 27), we should be talking about "writing processes" rather than "the writing process" (Russell, 1999, p. 80).

Pedagogically speaking, a belief in "writing processes" rather than "the process" may discourage teachers from creating a writing syllabus according to which all students at the same time should brainstorm, first-draft, write, and edit. On the other hand, however, it can improve practice in two regards. First, teachers, adopting a post-process mentality, will find it worthwhile to think about the usually invisible processes that writing students are more comfortable with, especially writing practices shaped by the impact of students' ethnicities, genders, cultures, first languages, and nonwritten literacies. Second, teachers, regarding students' practices as valid alternatives, will open up spaces for students to take charge of their own processes at their own pace and for their own purposes.

The main cause of process theorists' belief in a single ultimate writing process was the dominance of cognitive paradigms that regarded the human brain as the control centre of the act of writing of each individual. This reductionist approach to writing theory would have an incidental undesirable consequence: an unconditional admiration for essayist literacy and the omission of other writing genres, and accordingly alternative voices, in educational establishments. This phenomenon will be the focus of the next argument.

2. Essayist literacy and the rhetoric of assertion should be challenged in order to broaden genre possibilities.

Claims for literacy per se are often in fact tacit claims for essay-text literacy, a form of literacy that is neither natural nor universal, but one cultural way of making sense among many others. Of course, this way of making sense is associated with mainstream middle-class and upper middle-class groups and is, in fact, best represented by 
the ideology and sometimes the practice of academics, the people who most often make claims for it. (Gee, 1986, p. 731)

Regarding the act of writing as a single teachable process has, in traditional classrooms, reduced the number of writing genres that students naturally engage with in their everyday lives to one: the essay. Process theory has made "the essay central to composition courses and the English curriculum at large" (Schilb, 1999, p. 198). Consistent with the structure of the essay, as a "thesis-driven" (Atkinson, 2003b, p. 52) form of writing, the dominant rhetoric in writing and composition classes has turned into the "rhetoric of assertion":

In one way or another, composing (at least the way it is often taught) has always seemed to be associated with asserting something to be true. Students are instructed to write an essay, which has usually meant to take a position on a subject (often stated in a "strong," "clear" thesis statement, which is itself expressed in the form of an assertion), and to construct a piece of discourse that then "supports" the position. Passages in an essay that do not support the position are judged irrelevant, and the essay is evaluated accordingly. (Olson, 1999, p. 9)

Concerns about the historical causes and consequences of the dominance of the Anglo-American essay in educational systems have been voiced in different intellectual camps. Feminist thinkers, for instance, have raised serious questions about the dominance of male forms of linguistic expression in public space (Irigaray, 1985; Kristeva, 1984; Pollock, 1998). They have tried to illustrate that patriarchy, in the name of objectivity and clarity, has given prominence to male forms of communication - such as essay and report writing - and has undermined the presence of écriture féminine (Cixous, Cohen, \& Cohen, 1976). Similarly, there have been attempts to illustrate how capitalist systems benefit from essayist literacy (Gee, 2008; Scollon \& Scollon, 1981), which can lead to considerations about the exclusion of the voices of the people who do not necessarily thrive in a capitalist system - for instance the working class. In second language writing also, next to investigations into the impact of race, gender, and class on L2 writing (Kubota, 2003), there has been a long conversation about intercultural (contrastive) rhetoric (Connor, Nagelhout, \& Rozycki, 2008; Kaplan, 1966), which in its critical manifestations (Kubota \& Lehner, 2004) has frequently criticized the assumed supremacy of Anglo-American rhetoric over other (especially eastern) rhetorics.

Once the ideological causes of the elevated status of the essay in composition classes are surfaced, some pedagogical patterns might emerge as well. If students' cultures, genders, and literacies (including their first languages and mother rhetorics) are in any form constricted by the dominance of the essay, one pedagogical solution to this problem is broadening genre possibilities in 
the classroom (Journet, 1999; Romano, 2000; Russell, 1999, p. 87) and inviting students to move beyond the essay (Burnham, 2001; Couture, 2011, p. 23; Root, 2003; Schilb, 1999). Thus, teaching post-process in this sense, rather than teaching the technique of writing, is teaching "text construction practices that negotiate different styles, genres, and writing traditions" (Matsuda et al., 2003, p. 157). Teaching writing, in other words, is teaching genre awareness (Canagarajah, 2001; Hart, Carlson, \& Eadie, 1980; Hyland, 2003; Shafer, 2012) and the ability to switch between genres.

\section{Writing should liberate students' agencies.}

An invitation to broaden genre possibilities in post-process theory should not be interpreted as an attack on the essay as a form of writing. Instead, it should be appreciated by an examination of the consequences of accommodating more genres. Post-process theorists believe that students' interactions with a variety of genres will give marginalized students a voice. Post-process advocates hold that genre flexibility and genre blending, in a post-process writing community, can consequently lead to the liberation of students' agencies. Students, experimenting with and employing different genres, can express themselves in writing forms that they feel comfortable with and challenge writing styles that have traditionally served more advantaged sectors of society.

DeJoy (1999) criticized process theory for "the absence of feminism and other rhetorical strategies in the texts upon which the process-model movement institutionalized itself as the ground of composition studies" (p. 165). Creating space in writing classes and writing communities for students' rhetorical strategies and genre tendencies-influenced by their class, genre, or ethnicity - can help students generate meaning as active agents of change. Clifford and Ervin (1999) wrote that in order to help a post-process student become a "civic writer" (p. 195), teachers should "create new possibilities for epistemological and discursive agency" (p. 188). Dobrin (1999), also, called for providing students with "opportunities to be critical participants in the very discourses that liberatory pedagogies promote or resist" (p. 140). As an example of challenging genre expectations for expression and civic resistance, Anzaldúa (2007), in Borderlands/La Frontera: The New Mestiza, used different written forms -including poetry - and dual lingual passages in order to challenge Spanish/English, Latino/white, man/woman, heterosexual/homosexual, and autobiography/fiction dichotomies.

Post-process teachers, similarly, need to think of the act of writing as a form of social activism driven by students' agencies. Here are some questions teachers can ask when facilitating this type of writing. How can I treat my students as writers with valuable opinions rather than writing students? What forms of writing can help my students express their views? How can the act of writing surface the voices of students and legitimize the genres they usually employ out of the classroom as a suitable vehicle for expression? Finally, how can students' writing activities better their lives and communities? 
Writing is not an individual activity; hence, teaching writing is practically creating the sociocultural circumstances in which individuals feel a genuine need to write. With an emphasis on the sociocultural context of writing, post-process theorists believe that the value of post-process theory lies in "its ability to take us beyond a focus on writing simply as a ... highly cognitive, individualist, largely asocial process" (Atkinson, 2003a, p. 10). Writing is a human activity propelled by social interactions that make the production of different forms of written language necessary. Post-process theory, thus, "refers to the shift in scholarly attention from the process by which the individual writer produces texts to larger forces that affect that writer and of which that writer is a part" (Dobrin, 1999, p. 132). In other words:

From a social perspective, artifacts such as written texts have been described by Prior (1998) as "material objects fashioned by people" that include "durable symbolic forms, like natural languages, mathematics, and specialized disciplinary discourses that may be inscribed in material objects, but that are also internalized by and distributed across persons" (pp. 30-31). From a political perspective, written artifacts are political documents in the sense that they are produced in power-infused settings such as classrooms and discourse communities, and are used to further political as well as intellectual and instructional agendas. (Casanave, 2003, p. 87)

If writing teachers considered "how much ideological work is ubiquitous in textual production" and looked at "the page as a unit of discourse - the very materiality of its design - as a site of ideological and epistemological concentration" (Dobrin et al., 2011, p. 2), they would more willingly come to terms with the fact that there is no simple pedagogy for teaching writing as an individually performed classroom activity. Teaching writing might be more meaningful if it were redefined as opening up spaces for writing students to immerse themselves in social interactions which require them to write and, as importantly, to write well. Community service writing and project-based writing are examples of how students can interact with writing motivated by causes that usually drive real writers to write. Illustrating community-service pedagogy, Julier (2001) discussed her experiences with a group of college students who, instead of a writing class, joined a community centre as volunteers and wrote about their experiences in that centre. Also, in a report on a project-based approach, Levis and Levis (2003) emphasized the importance of publishing students' writings for the wider public. In their case study, international graduate students in an English academic writing class for non-native speakers defined a research project at the beginning of the course that would act as an umbrella to cover and inform all their activities in the class and thus render them as writing 
practices at the service of a meaningful and purposeful piece of writing. Writing teachers, thus, need to consider the fact that written language is produced in social circumstances that can be modelled in writing classes and communities.

\section{Teachers need to move beyond the classroom as the only rhetorical situation and} their role as the possessor of the techne of writing.

Harmonious with the visions of democratic education (Dewey, 1916), process theory had promised to create classrooms in which every student could learn to write. Ironically, however, creating a well-defined classroom pedagogybased on the writing process - process theory placed a "stubborn grip on students' composing efforts" (Couture, 1999, p. 30). Similar to the product-based traditions that process theory was criticizing, process pedagogy continued to teach "students to model technique rather than to emulate expression" (p. 30). Process pedagogy in practice thus turned into "general writing skills instruction" (Petraglia, 1999, p. 49) and teaching the techne of writing (Hawk, 2004).

In other words, despite the initial democratic notion that every child was a potential writer, educational systems again created a caste system in which the teachers - and a few brilliant students - possessed the techne of writing, and the students, lacking the cognitive ability to write, had to acquire the techne by means of emulation and copying. "[T]he death of authority in the classroom" (Ewald, 1999, p. 127) was hence a myth that never turned into reality. "Pedantry clearly is one paradigm the process movement [has] failed to subvert" (Couture, 1999, p. 30).

In contrast, from a post-process perspective, teaching writing should not be reduced to teaching vocabulary, grammar, or paragraph structuring. These skills, instead, should be organically acquired when students reflect on different genres and attempt to address different audiences in a variety of hermeneutic events. Teachers in a post-process community, accordingly, should facilitate expression, meaning making, and the distribution of students' ideas in different cultural networks. According to post-process theory, "writing ... is essentially learnt, not taught, and the teacher's role is to be non-directive and facilitating, assisting writers to express their own meanings through an encouraging and co-operative environment with minimal interference" (Hyland, 2003, p. 18).

\section{Written texts should be regarded as products of a complicated web of cultural practices, social interactions, power differentials, and discursive conventions.}

One important step beyond the writing-as-techne discourse in post-process writing communities is creating opportunities for students to see written texts as products of complicated societal, political, ideological, and discursive networks (Ewald, 1999; Matsuda, 2003, p. 157; Petraglia, 1999, p. 53). Writing students need to identify cultural practices that yield quality writing. 
They should see in which sectors of society these practices are more prevalent. They should analyze how written language facilitates social interactions, empowers some members of society, and oppresses others. Students need to be assisted in identifying stakeholders in power relations that surround text production and distribution. They should be encouraged to find their place in power networks in order to make their voices heard. They also need to become conscious about how literacy and writing are defined in their own communities and in dominant discourses in society.

In this regard, an ethnographic approach to learning and teaching writing can fit well in post-process pedagogy. Sinor and Huston (2004) wrote about ethnographic assignments that allowed struggling students to compare their own literacy practices with those of other people. In the case they focused on, a student was asked to investigate the literacy practices of his cousin believed to have a "highly literate home life" (p. 377). This story resembles another case study conducted by Hagemann (2001), in which a student was encouraged to "overtly compare ... home discourse and school discourse" (p. 75) to see what they already knew and what they needed to learn. Hagemann called this practice a "pedagogy of overt comparison" (p. 77).

When written texts are presented to students as means of social action and vehicles of empowerment, they will automatically find ways to learn the techne required to produce texts of acceptable quality. Post-process, in this spirit, is a move from "mastery to analysis" (DeJoy, 1999, p. 166).

7. Teaching writing is basically teaching rhetorical sensitivity and hermeneutic guessing through a large number of literate activities.

When two people communicate, they guess, generally in a highly effective manner, about the meaning of one another's discourse. This guess may be best understood as an ongoing attempt to align or to triangulate another person's discourse with language employed by other language users and with the world. (Kent, 2011, p. xiii)

As discussed in the previous argument, creating awareness about societal, political, and discursive dimensions of writing can indeed help students array and improve their literate lives. In the same manner, teaching writing should be regarded as teaching "rhetorical sensitivity" (Covino, 2001; Hart \& Burks, 1972, p. 91; Hart et al., 1980; Petraglia, 1999, p. 62). In post-process writing communities, students take control of arranging the messages in what they write considering the audience they need to address. They learn to express their views in order to find entry into power relations and social interactions to create change for themselves and the people around them, whether through a poem or an academic essay, whether in English or their first language. Students, from a post-process perspective, should be provided with genre awareness (Hyland, 2003) in order to master mainstream genres, reinforce their native genres, and challenge dominant genres. 
Rhetorical sensitivity shares many aspects with another concept commonly used by post-process theorists: hermeneutic guessing (Blyler, 1999, p. 67; Couture, 1999, p. 26; Dobrin, 1999, p. 140; Foster, 1999, p. 152; Kent, 1993). Borrowing the term hermeneutic guessing from Kent (1993), Dobrin (1999) defined the expression as follows: "Effective communicative interaction relies on strategies of ... 'hermeneutic guessing' wherein participants develop strategies based on previous experience to interpret discourse for that moment of communication" (p. 140).

Post-process practice, accordingly, should attempt to create authentic moments of communication to encourage hermeneutic guessing. Students' powers of rhetorical sensitivity and hermeneutic guessing, however, will not be sharpened without "a range of literate activities" (Clifford \& Ervin, 1999, p. 179 ) and "interaction with a variety of texts" (p. 192). Students should be encouraged to write and perform in their mother tongues and other languages they might know. They should sharpen their intercultural skills by gaining knowledge about their host culture. They should read, watch films, go to art galleries, mingle with different communities and circles, and navigate the dominant social practices systems of communication in their host countries. In post-process writing communities, accordingly, learning writing is more than a form of practice for mastery; it occurs as "praxis ... a composition process that promotes in rhetors both critical reflection and an informed and ethical impulse towards intervention into the public sphere" (Clifford \& Ervin, 1999, p. 179).

\section{Conclusion}

Through a systematic synthesis of the literature on post-process writing theory, this article tried to offer a definition of post-process second language writing. As a reaction to concerns about the pedagogical applicability of postprocess theory, the definition put forth in this article was consciously formed to readily lend itself to actual practice of L2 writing teaching and learning. This definition was offered as seven focal post-process arguments. These arguments illustrate how moving beyond the classroom, undermining the role of the teacher as the possessor of the techne, and disregarding the idea of a codifiable universal process of writing can help L2 writers regard writing as a social discursive phenomenon and perform the act of writing as sociocultural action for betterment of their lives.

\section{The Author}

Amir Kalan is a Ph.D. candidate in Language and Literacies Education at the University of Toronto. His research interests include rhetoric, hermeneutics, composition studies, multilingual text creation, translingual writing, and digital writing. As a practitioner, he has been teaching English as an additional language for 15 years in Canada and abroad. 


\section{References}

Anzaldúa, G. (2007). Borderlands/la frontera: The new mestiza (3rd ed.). San Francisco, CA: Aunt Lute Books.

Atkinson, D. (2003a). L2 writing in the post-process era: Introduction. Journal of Second Language Writing, 12(1), 3-15. doi:10.1016/S1060-3743(02)00123-6

Atkinson, D. (2003b). Writing and culture in the post-process era. Journal of Second Language Writing, 12(1), 49-63. doi:10.1016/S1060-3743(02)00126-1

Barton, D., \& Hamilton, M. (2000). Literacy practices. In D. Barton, M. Hamilton, \& R. Ivanic (Eds.), Situated literacies: Reading and writing in context (pp. 7-15). London, UK: Routledge.

Blyler, N. (1999). Research in professional communication: A post-process perspective. In T. Kent (Ed.), Post-process theory: Beyond the writing process paradigm (pp. 65-79). Carbondale, IL: Southern Illinois University Press.

Burnham, C. (2001). Expressive pedagogy: Practice/theory, theory/practice. In G. Tate, A. Rupiper, \& K. Schick (Eds.), A guide to composition pedagogies (pp. 19-35). New York, NY: Oxford University Press.

Canagarajah, S. (2001). The fortunate traveler: Shuttling between communities and literacies by economy class. In D. Belcher \& U. Connor (Eds.), Reflections on multiliterate lives (pp. 23-37). Clevedon, UK: Multilingual Matters.

Carnap, R. (1937). The logical syntax of language. London, UK: Kegan Paul, Trench, Trubner \& Co.

Casanave, C. P. (2003). Looking ahead to more sociopolitically-oriented case study research in L2 writing scholarship (but should it be called "post-process"?). Journal of Second Language Writing, 12(1), 85-102. doi:10.1016/S1060-3743(03)00002-X

Cazden, C., Cope, B., Fairclough, N., Gee, J., Kalantzis, M., Kress, G., ... Nakata, N. M. (1996). A pedagogy of multiliteracies: Designing social futures. Harvard Educational Review, 66(1), 60-93.

Cixous, H., Cohen, K., \& Cohen, P. (1976). The laugh of the Medusa. Signs, 1(4), 875-893.

Clifford, J., \& Ervin, E. (1999). The ethics of process. In T. Kent (Ed.), Post-process theory: Beyond the writing process paradigm (pp. 179-197). Carbondale, IL: Southern Illinois University Press.

Connor, U., Nagelhout, E., \& Rozycki, W. (2008). Contrastive rhetoric: Reaching to intercultural rhetoric. Philadelphia, PA: John Benjamins.

Couture, B. (1999). Modeling and emulating: Rethinking agency in the writing process. In T. Kent (Ed.), Post-process theory: Beyond the writing process paradigm (pp. 30-48). Carbondale, IL: Southern Illinois University Press.

Couture, B. (2011). Writing and accountability. In S. I. Dobrin, J. A. Rice, \& M. Vastola (Eds.), Beyond postprocess (pp. 21-40). Logan, UT: Utah State University Press.

Covino, W. A. (2001). Rhetorical pedagogy. In G. Tate, A. Rupiper, \& K. Schick (Eds.), A guide to composition pedagogies (pp. 36-53). New York, NY: Oxford University Press.

Cumming, A. (2013a). Multiple dimensions of academic language and literacy development. Language Learning, 63, 130-152. doi:10.1111/j.1467-9922.2012.00741.x

Cumming, A. (2013b). Where do language, literacy, and culture intersect? [Video file]. Retrieved from http://www.youtube.com/watch?v=joIm_tTsuP4

Cummins, J. (2009). Transformative multiliteracies pedagogy: School-based strategies for closing the achievement gap. Multiple Voices for Ethnically Diverse Exceptional Learners, 11(2), 38-56.

DeJoy, N. C. (1999). I was a process-model baby. In T. Kent (Ed.), Post-process theory: Beyond the writing process paradigm (pp. 163-178). Carbondale, IL: Southern Illinois University Press.

Derrida, J. (2001). Writing and difference (A. Bass, Trans.). London, UK: Routledge.

Dewey, J. (1916). Democracy and education: An introduction to the philosophy of education. New York, NY: Macmillan.

Dobrin, S. I. (1999). Paralogic hermeneutic theories, power, and the possibility for liberating pedagogies. In T. Kent (Ed.), Post-process theory: Beyond the writing process paradigm (pp. 132-148). Carbondale, IL: Southern Illinois University Press. 
Dobrin, S. I., Rice, J. A., \& Vastola, M. (Eds.). (2011). Beyond postprocess. Logan, UT: Utah State University Press.

Ewald, H. R. (1999). A tangled web of discourses: On post-process pedagogy and communicative interaction. In T. Kent (Ed.), Post-process theory: Beyond the writing process paradigm (pp. 116-131). Carbondale, IL: Southern Illinois University Press.

Foster, D. (1999). The challenge of contingency: Process and the turn to the social in composition. In T. Kent (Ed.), Post-process theory: Beyond the writing process paradigm (pp. 149-162). Carbondale, IL: Southern Illinois University Press.

Foucault, M. (2002). The archaeology of knowledge. London, UK: Routledge.

Fraiberg, A. (2002). Review: Houses divided: Processing composition in a post-process time. College Literature, 29(1), 171-180.

Fulkerson, R. (2005). Composition at the turn of the twenty-first century. College Composition and Communication, 56(4), 654-687.

Gee, J. P. (1986). Orality and literacy: From the savage mind to ways with words. TESOL Quarterly, 20(4), 719-746. doi:10.2307/3586522

Gee, J. P. (2001). What is literacy? In P. Shannon (Ed.), Becoming political, too: New readings and writings on the politics of literacy education (pp. 1-9). Portsmouth, NH: Heinemann.

Gee, J. P. (2008). Social linguistics and literacies: Ideology in discourses (3rd ed.). London, UK: Routledge.

Hagemann, J. (2001). A bridge from home to school: Helping working class students acquire school literacy. English Journal, 90(4), 74-81.

Hart, R. P., \& Burks, D. M. (1972). Rhetorical sensitivity and social interaction. Speech Monographs, 39(2), 75-91. doi:10.1080/03637757209375742

Hart, R. P., Carlson, R. E., \& Eadie, W. F. (1980). Attitudes toward communication and the assessment of rhetorical sensitivity. Communication Monographs, 47(1), 1-22. doi:10.1080/03637758009376016

Hawk, B. (2004). Toward a post technê-or, inventing pedagogies for professional writing. Technical Communication Quarterly, 13(4), 371-392. doi:10.1207/s15427625tcq1304_2

Heard, M. (2008). What should we do with postprocess theory? Pedagogy, 8(2), 283-304. doi:10.1215/15314200-2007-041

Heath, S. B. (1983). Ways with words: Language, life, and work in communities and classrooms. Cambridge, UK: Cambridge University Press.

Heath, S. B., \& Street, B. V. (2008). On ethnography: Approaches to language and literacy research. New York, NY: Teachers College Press.

Howard, R. M. (2001). Collaborative pedagogy. In G. Tate, A. Rupiper, \& K. Schick (Eds.), A guide to composition pedagogies (pp. 54-70). New York, NY: Oxford University Press.

Hyland, K. (2003). Genre-based pedagogies: A social response to process. Journal of Second Language Writing, 12(1), 17-29. doi:10.1016/S1060-3743(02)00124-8

Irigaray, L. (1985). Speculum of the other woman. Ithaca, NY: Cornell University Press.

Journet, D. (1999). Writing within (and between) disciplinary genres: The "adaptive landscape" as a case study in interdisciplinary rhetoric. In T. Kent (Ed.), Post-process theory: Beyond the writing process paradigm (pp. 96-115). Carbondale, IL: Southern Illinois University Press.

Julier, L. (2001). Community-service pedagogy. In G. Tate, A. Rupiper, \& K. Schick (Eds.), A guide to composition pedagogies (pp. 132-148). New York, NY: Oxford University Press.

Kaplan, D. (1972). What is Russell's theory of descriptions? In D. F. Pears (Ed.), Bertrand Russell: A collection of critical essays (pp. 227-244). Garden City, NY: Anchor Books.

Kaplan, R. B. (1966). Cultural thought patterns in inter-cultural education. Language Learning, 16(1-2), 1-20. doi:10.1111/j.1467-1770.1966.tb00804.x

Kent, T. (1993). Paralogic rhetoric: A theory of communicative interaction. Cranbury, NJ: Associated University Presses.

Kent, T. (Ed.). (1999). Post-process theory: Beyond the writing-process paradigm. Carbondale, IL: Southern Illinois University Press. 
Kent, T. (2002). Principled pedagogy: A reply to Lee-Ann M. Kastman Breuch. JAC, 22(2), 428433.

Kent, T. (2011). Preface: Righting writing. In S. I. Dobrin, J. A. Rice, \& M. Vastola (Eds.), Beyond postprocess (pp. xi-xxii). Logan, UT: Utah State University Press.

Kristeva, J. (1984). Revolution in poetic language. New York, NY: Columbia University Press.

Kubota, R. (2003). New approaches to gender, class, and race in second language writing. Journal of Second Language Writing, 12(1), 31-47. doi:10.1016/S1060-3743(02)00125-X

Kubota, R., \& Lehner, A. (2004). Toward critical contrastive rhetoric. Journal of Second Language Writing, 13(1), 7-27. doi:10.1016/j.jslw.2004.04.003

Leki, I. (2003). Coda: Pushing L2 writing research. Journal of Second Language Writing, 12(1), 103105. doi:10.1016/S1060-3743(02)00128-5

Levis, J. M., \& Levis, G. M. (2003). A project-based approach to teaching research writing to nonnative writers. IEEE Transactions on Professional Communication, 46(3), 210-220. doi:10.1109/ TPC.2003.816788

Lycan, W. G. (2000). Philosophy of language: A contemporary introduction. London, UK: Routledge.

Matsuda, P. K. (2003). Process and post-process: A discursive history. Journal of Second Language Writing, 12(1), 65-83. doi:10.1016/S1060-3743(02)00127-3

Matsuda, P. K., Canagarajah, A. S., Harklau, L., Hyland, K., \& Warschauer, M. (2003). Changing currents in second language writing research: A colloquium. Journal of Second Language Writing, 12(2), 151-179. doi:10.1016/S1060-3743(03)00016-X

Odell, S. J. (2006). On the philosophy of language. Belmont, CA: Thomson Wadsworth.

Olson, G. A. (1999). Toward a post-process composition: Abandoning the rhetoric of assertion. In T. Kent (Ed.), Post-process theory: Beyond the writing process paradigm (pp. 7-15). Carbondale, IL: Southern Illinois University Press.

Petraglia, J. (1999). Is there life after process? The role of social scientism in a changing discipline. In T. Kent (Ed.), Post-process theory: Beyond the writing process paradigm (pp. 49-64). Carbondale, IL: Southern Illinois University Press.

Pollock, G. (1998). To inscribe in the feminine: A Kristevan impossibility? Or femininity, melancholy and sublimation. Parallax, 4(3), 81-117. doi:10.1080/135346498250136

Prior, P. A. (1998). Writing/disciplinarity: A sociohistoric account of literate activity in the academy. Mahwah, NJ: Lawrence Erlbaum Associates.

Pullman, G. (1999). Stepping yet again into the same current. In T. Kent (Ed.), Post-process theory: Beyond the writing process paradigm (pp. 16-29). Carbondale, IL: Southern Illinois University Press.

Romano, T. (2000). Blending genre, altering style: Writing multigenre papers. Portsmouth, NH: Boynton/Cook.

Root, R. L. (2003). Naming nonfiction (a polyptych). College English, 65(3), 242-256.

Russell, B. (2005). On denoting. Mind, 114(456), 873-887. doi:10.1093/mind/fzi873

Russell, D. (1999). Activity theory and process approaches: Writing (power) in school and society. In T. Kent (Ed.), Post-process theory: Beyond the writing process paradigm (pp. 80-95). Carbondale, IL: Southern Illinois University Press.

Sanchez, R. (2011). First, a word. In S. I. Dobrin, J. A. Rice, \& M. Vastola (Eds.), Beyond postprocess (pp. 183-194). Logan, UT: Utah State University Press.

Schilb, J. (1999). Reprocessing the essay. In T. Kent (Ed.), Post-process theory: Beyond the writing process paradigm (pp. 198-214). Carbondale, IL: Southern Illinois University Press.

Scollon, R., \& Scollon, S. B. K. (1981). Narrative, literacy, and face in interethnic communication. Norwood, NJ: Ablex.

Shafer, G. (2012). Living in the post-process writing center. Teaching English in the Two-Year College, 39(3), 293-305.

Simon, R. (2011). On the human challenges of multiliteracies pedagogy. Contemporary Issues in Early Childhood, 12(4), 362-366. 
Sinor, J., \& Huston, M. (2004). The role of ethnography in the post-process writing classroom. Teaching English in the Two-Year College, 31(4), 369-382.

Street, B. V. (Ed.). (1993). Cross-cultural approaches to literacy. New York, NY: Cambridge University Press.

Susser, B. (1994). Process approaches in ESL/EFL writing instruction. Journal of Second Language Writing, 3(1), 31-47. doi:10.1016/1060-3743(94)90004-3

Trimbur, J. (1994). Review: Taking the social turn: Teaching writing post-process. College Composition and Communication, 45(1), 108-118.

Trimbur, J., \& Press, K. (2011). The page as a unit of discourse: Notes toward a counterhistory for writing studies. In S. I. Dobrin, J. A. Rice, \& M. Vastola (Eds.), Beyond postprocess (pp. 94-113). Logan, UT: Utah State University Press.

White, R. V. (1988). Academic writing: Process and product. In P. C. Robinson (Ed.), Academic writing: Process and product (pp. 4-16). London, UK: Modern English Publications and the British Council.

White, R. V., \& Arndt, V. (1991). Process writing. New York, NY: Longman.

Wittgenstein, L. (1958). Philosophical investigations (G. E. M. Anscombe, Trans., 2nd ed.). Oxford, UK: Basil Blackwell. 